Ambiente \& Água - An Interdisciplinary Journal of Applied Science
ISSN 1980-993X - doi:10.4136/1980-993X
www.ambi-agua.net
E-mail: ambi-agua@agro.unitau.br

\title{
Antimicrobial resistance in bacteria isolated from aquatic environments in Brazil: a systematic review
}

\author{
doi: 10.4136/ambi-agua.1343
}

Received: 18 Mar. 2014; Accepted: 26 May 2014

\author{
Ermeton Duarte do Nascimento; Magnólia Fernandes Florêncio de Araújo* \\ Universidade Federal do Rio Grande do Norte (UFRN), Natal, RN, Brasil \\ Department of Microbiology and Parasitology \\ *Corresponding author: e-mail: magffaraujo@gmail.com, \\ ermeton_duarte@yahoo.com.br
}

\begin{abstract}
This article discusses antibiotic resistance in bacteria isolated from aquatic environments in Brazil, taking into account isolation sites, the main reported antimicrobial agents, the genes involved in resistance, the most prevalent bacterial genera and species, and the main mechanisms of resistance. This review is based upon specialized literature, consulting published scientific articles selected from the SciELO, PubMed and LILACS databases. Based upon the inclusion criteria, we selected 21 articles, most $(61.6 \%)$ were from PubMed, with the highest prevalence for work done in the Southeast region $(71.4 \%)$ in freshwater environments (71.4\%), and the major focus on farm ponds (28.6\%). Gram-negative bacteria are the most studied (71.4\%) and the Aeromonas spp. was the one found most frequently (19.0\%). The most frequently used antimicrobials were chloramphenicol (81.0\%), gentamicin (76.2\%), sulpha/trimethroprim (71.4\%), ampicillin (61.9\%) and tetracycline (71.4\%); and the ones with higher prevalence of resistance were chloramphenicol $(58.8 \%)$, sulpha/trimethroprim (78.5\%) and ampicillin (84.6\%). It was found that studies on resistance in other aquatic environments have not yet been conducted in Brazil, especially in the North and Northeast regions, where irregular rainfall distribution leads to the use of reservoirs as supply sources during the dry season, highlighting concerns regarding the quality, contamination and maintenance of these resources, as the water is intended for human use or for production purposes.
\end{abstract}

Keywords: microorganisms, antibiotic resistance, water pollution.

\section{Resistência antimicrobiana em bactérias isoladas de ambientes aquáticos no Brasil: uma revisão sistemática}

\section{RESUMO}

Este artigo tem como objetivo discutir a resistência antimicrobiana em bactérias isoladas de ambientes aquáticos no Brasil, levando em conta os locais de isolamento, os principais agentes antimicrobianos relatados, os genes envolvidos na resistência, os gêneros e espécies bacterianas mais prevalentes e os principais mecanismos de resistência presentes. Trata-se de uma revisão bibliográfica sistemática baseada em literatura especializada por meio de consulta a artigos científicos publicados e selecionados através de busca em bancos de dados 
da SciELO, PubMed e LILACS. Após o uso dos critérios de inclusão foram selecionados 21 artigos, a maioria $(61,6 \%)$ do PubMed, com maior prevalência para os trabalhos realizados na região sudeste $(71,4 \%)$, em ambientes de água doce $(71,4 \%)$, e com o maior foco para os tanques de cultivo $(28,6 \%)$. As bactérias Gram-negativas foram as mais estudadas $(71,4 \%)$ e a espécie Aeromonas spp. foi a mais encontrada (19,0\%) nesses estudos. Os antimicrobianos mais frequentemente utilizados foram cloranfenicol $(81,0 \%)$, gentamicina $(76,2 \%)$, sulpha/trimetropim $(71,4 \%)$, ampicilina $(61,9 \%)$ e tetraciclina $(71,4 \%)$. E os de maior prevalência de resistência foram cloranfenicol (58,8\%), sulpha/trimetropim $(78,5 \%)$ e ampicilina $(84,6 \%)$. Percebeu-se que estudos futuros sobre a resistência em outros ambientes aquáticos ainda precisam ser realizados no Brasil, principalmente na região Norte e Nordeste, onde a distribuição irregular das chuvas leva a utilização dos reservatórios como fontes de abastecimento durante o período de estiagem e assim as preocupações quanto aos níveis de qualidade, contaminação e manutenção desses recursos assumem grande importância, à medida que a água é destinada à utilização humana ou para fins produtivos.

Palavras-chave: microrganismos, resistência antibiótica, poluição da água.

\section{INTRODUCTION}

Bacterial resistance to antimicrobials is a genetic phenomenon caused by genes within the organism that encode different biochemical mechanisms and prevent the action of these drugs (Aminov, 2009; Gonzalez-Candelas et al., 2011). Nowadays, both in developed and developing countries, antimicrobial resistance is a concern and an epidemiological problem (Chandran et al., 2008).

In the early 90s resistant pathogens characteristic of the hospital environment were first observed, causing infections in healthy individuals. The biggest concern regarding these infections was the identification of a bacterium resistant to antimicrobial agents in aquatic environments, since these environments are used for various purposes.

The problem with antimicrobial resistance in the aquatic environment is even more serious because some bacteria have the ability to transfer their genes to others, including to those of different species living in the same environment, and there are reports of conjugative and translational plasmid transfers between microbial strains resistant to antibiotics, isolated in these environments (Hatha et al., 1993).

In this context, considering that Brazil has a large variety of aquatic environments, the purpose of this paper is to describe and systematically analyze works recently published about this phenomenon in various databases.

\section{MATERIALS AND METHODS}

This study consisted of a systematic review, conducted between June and September of 2013, in which scientific articles in LILACS, SciELO and PubMed databases were consulted. The search was limited to articles published from 1988 to 2013 and used the key words "water", "antibiotic" and "resistance", proposed by the Virtual Health Library. The search for key words was done not only in English, but also in Portuguese and Spanish.

The review included all studies that had as their main focus any kind of resistance to antimicrobials (antibiotics, semi synthetic and/or chemotherapeutic) in bacteria isolated from Brazilian aquatic environments. Studies that did not have resistance as the main focus were excluded, as were those whose source environment of bacterial isolation was not water, those that only cited the resistance in the body text, those that were conducted in another country other than Brazil, those conducted with any organism other than bacteria, and those that found bacterial resistance to other pharmacological groups different from antimicrobials. 
The goal was to compare and discuss antibiotic resistance in bacteria isolated from aquatic environments in Brazil, observing the main aquatic environments where these microorganisms had been isolated, the main reported antimicrobial agents, the genes involved in resistance, the genera, the most prevalent bacterial species and the main resistance mechanisms present.

\section{RESULTS AND DISCUSSION}

A total of 1014 publications were found in the databases consulted during the period from June to September of 2013, and out of these, after the exclusion criteria were applied, twenty-one publications, nineteen articles, a dissertation and a doctoral thesis were selected. Thirteen of them $(61.9 \%)$ were published in PubMed, five $(23.8 \%)$ in LILACS and three (14.3\%) in SciELO. The publications are concentrated between the years of 1995 and 2012, being 2008 the year with the highest percentage (19\%). Among the Brazilian states where there were the greatest numbers of studies on the subject, Rio de Janeiro (38.1\%), Minas Gerais $(19.0 \%)$ and São Paulo (14.3\%) stand out. During this period, in the northeast region of Brazil, only three articles were published (14.3\%) in the states of Ceará and Rio Grande do Norte (Table 1). Altogether, $71.4 \%$ of them have involved isolation of bacteria from freshwater and the most studied environment was the water used in tanks for the cultivation of fish or shrimp $(28.6 \%)$. The group of Gram-negative bacteria has been the most studied (71.4\%) and the Aeromonas spp. was the one most frequently found in these studies $(19.0 \%)$. The classic techniques for bacterial identification presented themselves as the most frequent among the analyzed studies $(85.7 \%)$ and the disk diffusion method was the most frequently used $(71.4 \%)$ to characterize the susceptibility profile of isolated microorganisms (Table 2).

Table 1. Database, type, year of publication and study sites of the articles surveyed during the period from June to September 2013.

\begin{tabular}{lcc}
\hline \multicolumn{1}{c}{ Characteristics } & $\mathbf{N}$ & \% \\
\hline Database & 3 & 14.3 \\
SciELO & 5 & 23.8 \\
LILACS & 13 & 61.9 \\
PubMed & & \\
\hline Type of Publication & 19 & 90.5 \\
Scientific Article & 2 & 9.5 \\
Other (Masters Dissertation and Doctoral Thesis) & & \\
\hline Year of Publication & 1 each & 4.8 each \\
1995, 2000, 2001, 2007, 2009 & 2 each & 9.5 each \\
2004, 2010, 2012 & 3 each & 14.3 each \\
2006, 2011 & 4 & 19.0 \\
2008 & & \\
States where the studies were made & 8 & 38.1 \\
Rio de janeiro & 4 & 19.0 \\
Minas Gerais & 3 & 14.3 \\
São Paulo & 2 & 9.5 \\
Paraná & 2 & 9.5 \\
Ceará & 1 & 4.8 \\
Rio Grande do Norte & 1 & 4.8 \\
In two different states & Total & $\mathbf{2 1}$ \\
\hline
\end{tabular}


Table 2. Environmental and methodological characteristics identified in the articles published during the period from June to September of 2013.

\begin{tabular}{lcc}
\multicolumn{1}{c}{ Characteristics } & N & \% \\
\hline Type of water researched & & 71.4 \\
Fresh water & 15 & 0 \\
Brackish water & 0 & 9.5 \\
Salt water & 2 & 4.8 \\
Freshwater and saltwater & 1 & 0 \\
Freshwater and brackish water & 0 & 4.8 \\
Salt water and brackish water & 1 & 9.5 \\
Freshwater, brackish and saltwater & 2 & \\
\hline
\end{tabular}

\section{Aquatic environments}

$\begin{array}{lcc}\text { Lake } & 1 & 4.8 \\ \text { Pond } & 1 & 4.8 \\ \text { Ocean } & 3 & 14.3 \\ \text { Sewage treatment plant } & 4 & 19.0 \\ \text { Cultivation Tank } & 6 & 28.6 \\ \text { Two different environments } & 2 & 9.5 \\ \text { Three or more different environments } & 2 & 9.5 \\ \text { Others } & 2 & 9.5\end{array}$

\section{Group of isolated bacteria}

$\begin{array}{lcc}\text { Gram-positive } & 2 & 9.5 \\ \text { Gram-negative } & 15 & 71.4 \\ \text { Gram-positive and Gram-negative } & 4 & 19.0\end{array}$

\section{Techniques for isolation and identification}

$\begin{array}{lcc}\text { Manual } & 18 & 85.7 \\ \text { Semi automated } & 1 & 4.8 \\ \text { Automated } & 0 & 0 \\ \text { Two or more techniques } & 2 & 9.5\end{array}$

\section{Antimicrobial susceptibility testing}

Disk diffusion

E-test

MIC (Minimum Inhibitory Concentration)

Joint

15

0

5

1
71.4

0

23.8

4.8

\section{Total}

21

100.0

Adding all the analyzed articles, 44 different antimicrobial agents were tested, being the most common: chloramphenicol (81.0\%), gentamicin $(76.2 \%)$, sulpha/trimethoprim $(71.4 \%)$, ampicillin $(61.9 \%)$ and tetracycline $(71.4 \%)$. These are also those with the highest resistance prevalence: chloramphenicol $(58.8 \%)$, gentamicin $(31.2 \%)$, sulpha/trimethoprim $(78.5 \%)$, ampicillin $(84.6 \%)$ and tetracycline $(53.3 \%)$ (Figure 1$)$. 


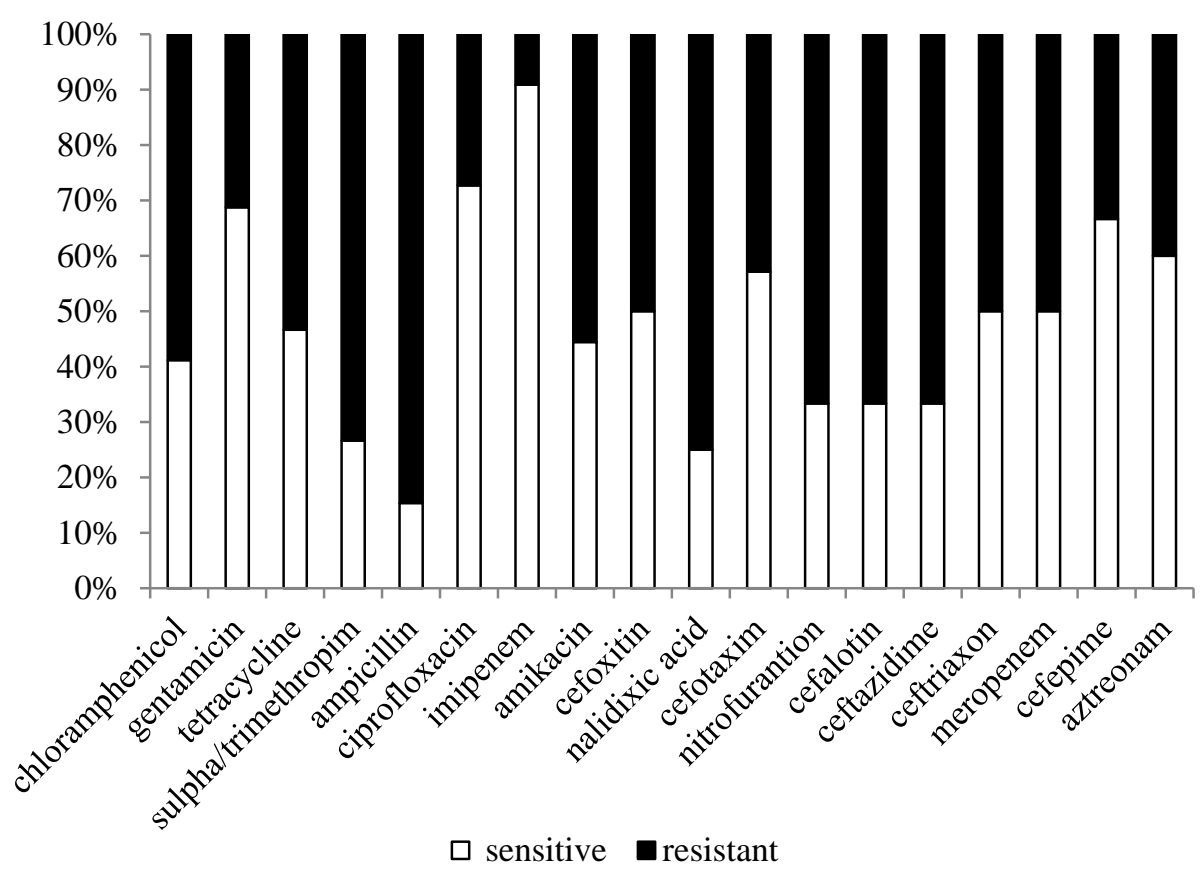

Figure 1. Susceptibility profile of the majority of antimicrobials tested in the surveyed articles.

The emergence of antimicrobial-resistant bacteria in aquatic environments has increased considerably (Miyake et al., 2003). During the last 25 years in Brazil, resistant bacteria have already been identified in river waters (De Mondino et al., 1995; Souza et al., 2000; Falcão et al., 2004), lakes and ponds; (De Mondino et al., 1995; Falcão et al., 2004; Pontes et al., 2009; Salloto et al., 2012) and in the sea (De Mondino et al., 1995; Falcão et al., 2004; Cardonha et al., 2004; De Oliveira and Pinhata, 2008; De Oliveira et al., 2010). Bacteria were also identified in sewage treatment stations (Prado et al., 2008; Souza et al., 2000; Ribeiro, 2011), in the water of tanks used for aquaculture (Hirsch et al., 2006; Pereira Júnior et al., 2006; Lima et al., 2006; Ribeiro et al., 2010; Ribeiro, 2011; Resende et al., 2012) and, even more worryingly, in drinking water (Silva et al., 2008).

A study conducted in Lakes Dom Helvécio, Gambazinho and Jacaré in Rio Doce/MG that compared samples from two different periods (2003 and 2005) in the same environments found a prevalence of $97 \%$ of Gram-negative bacteria and only 3\% of Gram-positive bacteria for all lakes; but the frequency of multi-resistant phenotypes varied between environments and periods, and showed an increased number of these phenotypes between the periods studied for each lake, indicating that the phenomenon of resistance has grown in these environments (Pontes et al., 2009).

In another study of lake and river waters, conducted in Araraquara, in the State of São Paulo, a prevalence of $50 \%$ of multi-resistance among the bacterial strains was found, and most of them seemed to be resistant to ampicillin (one semi synthetic penicillin) and various cephalosporins (Falcão et al., 2004). In a study carried out with river water in the city of Rio de Janeiro, the authors also found resistance to penicillin for Bacteroides fragilis, but with an index of $100 \%$ for this class of drug (Souza et al., 2000).

Surface water can be contaminated by various sources, including urban or farm runoff, discharges from wastewater treatment facilities, excreta of wild animals or even rain water. Human exposure to this contaminated water, such as by ingesting drinking water or during recreational activities, is a significant route for intestinal pathogens (Cardonha et al., 2004). 
Environmental contamination is directly linked to population growth. To the extent that the population grows, anthropogenic impacts affect lakes, rivers and coastal ecosystems, mainly due to the discharge of sewage and chemical compounds, such as pesticides, in addition to hormones and antibiotics that are widely used in human and veterinary clinical practice (Salloto et al., 2012).

The main source of antibiotics in aquatic environments comes from the discharge of wastewater, disposal of waste and aquaculture (Ding and He, 2010), and the increased levels of antimicrobial resistance among bacterial strains isolated from polluted aquatic environments, particularly in developing countries, which may be an indicative of overuse or misuse of antimicrobial agents in these environments (Souza et al., 2000).

In Brazil, most studies of bacterial antimicrobial resistance relate to water aquaculture (Hirsch et al., 2006; Pereira Junior et al., 2006; Lima et al., 2006; Ribeiro et al., 2010; Rebouças et al., 2011; Resende et al., 2012). In a study done with eight tilapia fish farms, in the Alto of Rio Grande region, Minas Gerais, bacteria were isolated from cultivation water, from the body surface area and renal parenchymal of the fish. All of the isolated bacteria were resistant to antimicrobials, with a multi-resistance index of $42.6 \%$ (Hirsch et al., 2006). More worrying results were found by Lima et al. (2006) in Lavras/MG, where a rate of $83 \%$ multiresistance has been identified in bacteria isolated from the tilapia water, the food used for the animals, as well as the body surface, the intestinal content and the fillets of fish caught for slaughter. All of this was identified and showed a higher prevalence of resistance to erythromycin (24\%) and ampicillin (23\%). In the same study comparison between the water used to supply the tanks and the water that was already in the cultivation tank was performed; a smaller number of microorganisms were isolated from the water supply, suggesting that the creation environment favors the increase of bacterial populations.

In the city of Rio de Janeiro, in a work which included the production of fertilizers for agriculture in a farm of fish culture supplied by sewage water that was pretreated by sedimentation, microorganisms were isolated in $100 \%$ of the samples from fish and vegetables and $93.3 \%$ of produced organic fertilizers, with an index of multi-resistance of $37.7 \%$, with a higher prevalence for sulpha/trimethropim $(64.2 \%)$ and tetracycline $(57.1 \%)$ (Ribeiro et al., 2010). According to the authors, in recent decades the use of wastewater in agriculture and aquaculture has grown, along with the increase in construction of culverts and sewages in urban areas, especially in arid and semi-arid areas, thus increasing the cost benefit relation of food production. In some cases, the treated wastewater has been used as water for cultivation, as a better alternative to replace the use of local surface contaminated water. The authors further argue that aquatic bacteria can be reservoirs for tet $(\mathrm{M})$ and tet $(\mathrm{S})$ genes, conferring resistance to tetracyclines and also other resistance profiles may be associated with the fact that it is not possible to completely remove all substances discharged into the environment, including antimicrobials, which leads to the selective pressure of these organisms and the emergence of resistance.

Another source for the study of antimicrobial resistance in bacteria isolated from aquatic environments is the analysis of the water of the sewage treatment plant, and some works in Brazil have been developed for this purpose. In Rio de Janeiro/RJ, in a study carried out with water from the hospital sewage treatment plant, the production of extended spectrum betalactamase (an enzyme that degrades beta-lactam antibiotics, i.e., penicillins) was found in $46.5 \%$ of Klebsiella pneumoniae isolated strains, showing a $26 \%$ rate of multi-resistance (Prado et al., 2008). According to the authors, various toxic substances, radioisotopes, hormones, drugs, heavy metals and pathogenic microorganisms, including bacteria with antimicrobial resistance may be found in sewage water issuing from health services. A worrisome note is that, in the studied treatment plant, there was only incomplete removal of 
pathogenic microorganisms that remain in effluents and these can contaminate other water sources.

According to De Oliveira and Pinhata (2008), although there have been recent studies aiming to describe the pattern of distribution of antibiotic-resistant bacteria in freshwater, estuarine water, water distribution systems and sewage, there are few studies in the marine environment and coastal zone. And in a study conducted by these authors in the city of São Vicente, located in Santos Lowland (Baixada Santista), São Paulo, Enterococcus spp. were isolated in $94.2 \%$ of the samples of sea water and sand. Of these, $51.9 \%$ were resistant to some antimicrobials, predominantly erythromycin and streptomycin.

This same study shows that other studies have demonstrated that beach sand can act as a reservoir and/or vector for a variety of diseases and that, although it is a fundamental part of recreational activities in the coastal environment, it has been largely neglected from the point of view of public health (De Oliveira and Pinhata, 2008).

All researched articles conducted tests with antimicrobials; there were a total of 44 different antimicrobial agents tested in the 21 articles evaluated. There was no uniformity of frequency of antimicrobials among the articles. Few studies have tested the same drugs. The same 17 antimicrobials and five antibiotics were repeated in more than 15 articles, they are ampicillin, chloramphenicol, gentamycin, tetracycline, and sulpha/trimethropim. Among the most tested antimicrobials, those with the highest prevalence of resistance to identified bacteria are chloramphenicol (58.8\%), sulpha/trimethropim (73.3\%) and ampicillin (84.6\%).

In a work performed in the city of Maringá/PR, a prevalence of $91 \%$ of ampicillin resistance was found in bacteria isolated from various aquatic environments (Scoaris et al., 2008), and in another study conducted in three rivers in the state of Ceará a frequency of $64.52 \%$ of intermediate resistance to this antimicrobial was found (Rebouças et al., 2011). Ampicillin resistance is usually associated with genes located on plasmids and some works developed in other countries have also found similar results (Pontes et al., 2009).

Only three studies investigated genes of antimicrobial resistance, two in Rio de Janeiro and one in Minas Gerais; all studied how genes encode resistance to beta-lactam antibiotics (Table 2). Souza et al. (2000), in Rio de Janeiro, working with strains of Bacteroides fragilis isolated from the aquatic environment, researched the cfiA gene, which encodes a metallobeta-lactamase, identified only in clinical specimens of B. fragilis from France, United States and United Kingdom, and contrasted the results with those of clinical samples of hospital environments in Brazil, finding a similar resistance profile among hospital and environmental strains.

Also in the city of Rio de Janeiro, Chagas (2011) researched the bla $a_{K P C}, b_{1} a_{T E M}, b^{\prime} a_{S H V}$ and bla $_{C T X-M}$ genes, coding extended spectrum beta-lactamase, in the treatment of hospital sewage and found a prevalence of $43 \%$ of these resistance genes isolated from the strain.

In Minas Gerais, in the Rio Doce Basin, the occurrence of the $b l a_{T E M 1}$ gene in cultivable Gram-negative bacteria isolated from environments exposed to anthropogenic activity was studied. This gene also encodes the production of a beta-lactamase. A predominance of nearly a $100 \%$ association between the resistance to ampicillin and the presence of the gene was found (Pontes et al., 2009) (Table 3).

In most of the studies published during the investigation period, the Gram-negative bacteria were the most prevalent microorganisms, almost all of them belonging to the Enterobacteriaceae family, which contains the group of coliforms (De Mondino et al., 1995; Souza et al., 2000; Falcão et al., 2004; Lima et al., 2006; Pereira Júnior et al., 2006; Hirsch et al., 2006; Scoaris et al., 2008; Prado et al., 2008; Silva et al., 2008; Pontes et al., 2009; Ribeiro et al., 2010; Rebouças et al., 2011; Ribeiro, 2011; Resende et al., 2012; Salloto et al., 2012), however, Gram-positive bacteria were also isolated (De Oliveira and Pinhata, 2008; Oliveira et al., 2010; Salloto et al., 2012). 
Table 3. Antimicrobial resistance genes surveyed in the assessed work.

\begin{tabular}{|c|c|c|c|c|c|}
\hline $\begin{array}{c}\text { Location/ } \\
\text { Year }\end{array}$ & Source & Isolated Species & $\begin{array}{l}\text { Gene/Resistance } \\
\text { Mechanism }\end{array}$ & $\begin{array}{l}\text { Profile of } \\
\text { resistance }\end{array}$ & Reference \\
\hline $\mathrm{RJ} / 2000$ & $\begin{array}{l}\text { River and } \\
\text { sewage } \\
\text { treatment } \\
\text { station }\end{array}$ & Bacteroides fragilis & $\begin{array}{c}\text { CfiA } \\
\text { Production of a } \\
\text { metallo- } \beta \text {-lactamase }\end{array}$ & $\begin{array}{l}\text { PEN, CFO, } \\
\text { CLI, MET }\end{array}$ & $\begin{array}{l}\text { Silva and Souza } \\
\text { et al. (2000) }\end{array}$ \\
\hline MG/2009 & Lake & $\begin{array}{l}\text { Acinetobacter } \mathrm{spp} . \\
\text { Enterobacter } \mathrm{spp} . \\
\text { Pseudomonas } \mathrm{spp} . \\
\text { Aeromona } \mathrm{spp} . \\
\text { Erwinia } \mathrm{spp} . \\
\text { Stenotrophomonas spp. } \\
\text { Morganella spp. } \\
\text { Serratia } \mathrm{spp} . \\
\text { Moraxella } \mathrm{spp} . \\
\text { Staphylococcus } \mathrm{spp} . \\
\text { Lactococcus } \mathrm{spp} .\end{array}$ & $\begin{array}{l}\text { bla-TEM1 } \\
\text { Production of a } \beta \text { - } \\
\text { lactamase }\end{array}$ & AMP & $\begin{array}{l}\text { Pontes et al. } \\
\text { (2009) }\end{array}$ \\
\hline $\mathrm{RJ} / 2011$ & $\begin{array}{l}\text { Sewage } \\
\text { treatment } \\
\text { station }\end{array}$ & $\begin{array}{c}\text { Escherichia coli } \\
\text { Klebsiella pneumoniae } \\
\text { Enterobacter cloacae } \\
\text { P. aeruginosa } \\
\text { A. baumannii } \\
\text { Aeromonas spp. }\end{array}$ & $\begin{array}{c}\text { bla-KPC } \\
\text { Production of a }-\beta \text { - } \\
\text { lactamase } \\
\\
\text { bla-TEM } \\
\text { Production of a }-\beta \text { - } \\
\text { lactamase } \\
\text { bla-SHV } \\
\text { Production of a } \beta \text { - } \\
\text { lactamase } \\
\\
\text { bla-CTX-M } \\
\text { Production of a }-\beta \text { - } \\
\text { lactamase }\end{array}$ & $\begin{array}{l}\text { CFO, MER, } \\
\text { CAZ, CFL, } \\
\text { CTX, AMI, } \\
\text { CIP, SUT, } \\
\text { COM, PPT }\end{array}$ & Chagas, 2011 \\
\hline
\end{tabular}

Nota:PEN = penicillin, $\mathrm{CFO}=$ cefoxitin, MER = meropenem, $\mathrm{CLI}=$ clindamycin, $\mathrm{MET}=$ metronidazole, $\mathrm{AMP}=$ ampicillin, CAZ = Ceftazidime, $\mathrm{CFL}=$ cephalothin, $\mathrm{CTX}=$ cefotaxime, $\mathrm{AMI}=$ amikacin, $\mathrm{CIP}=$ ciprofloxacin, SUT $=$ sulpha/trimethoprim CPM $=$ cefepime, $\mathrm{PPT}=$ piperacillin/tazobactam .

The Enterococcus spp. was the most prevalent among the Gram-positive (De Oliveira and Pinhata, 2008; Oliveira et al., 2010; Resende et al., 2012) and the Aeromonas spp. was the most prevalent among the Gram-negative and among all surveyed works (Hirsch et al., 2006; Pereira Júnior et al., 2006; Scoaris et al., 2008;. Pontes et al., 2009; Ribeiro et al., 2010; Ribeiro, 2011). Only one reported study found the isolation of the V. cholerae (Reboças et al., 2011).

In Lavras/MG, in a study conducted with surface water, out of all the isolated bacteria, $44 \%$ belonged to the Gram-negative group (Lima et al., 2006). However, in another study in the city of Leopoldina, also in the state of Minas Gerais, a prevalence of $76.16 \%$ for Gramnegative was found, with $47.91 \%$ belonging to the Enterobacteriaceae family (Resende et al., 2012).

The prevalence of Gram-negative in the aquatic environment has been already reported, especially those of the coliform group. More than $50 \%$ of the diseases caused by 
contaminated water are associated with bacteria from the intestinal micro biota, such as Enterobacteriaceae and the coli form group. The contamination of these environments reflects the poor quality, hygiene and sanitization of the water. Also, $4 \%$ of all deaths and $5.7 \%$ of all infectious diseases in the world are associated with contaminated water (Salloto et al., 2012).

Several studies of water found similar data for Aeromonas spp. In Alto of the Rio Grande region, MG, the highest percentage of isolated Aeromonas (70\%) was from an aquaculture reservoir water and the most prevalent species were A. jandaei and A. hydrophila with $26.67 \%$ and $25.33 \%$ respectively (Hirsch et al., 2006). The interest in the study of this organism is directly connected to aquaculture because this bacterium is recognized as a pathogen of fish, which can cause severe hemorrhagic septicemia, with serious economic losses (Ribeiro et al., 2010). These findings explain the greater amount of works focused on aquaculture and the interest in the isolation of Aeromonas spp. in Brazil.

The isolation of Aeromonas spp. and the interest in their identification can also be attributed to the fact that human exposure to contaminated water by this pathogen, through ingestion or even direct contact, has been associated with various infections, especially in immune-compromised individuals (Pereira Júnior et al., 2006;. Ribeiro et al., 2010) elderly and children (Scoaris et al., 2008).

Resistance mechanisms discussed in the works are mostly focused on the production of enzymes that degrade antimicrobials, such as beta-lactamases, and some studies have calculated the index of Multiple Antibiotic Resistance (MAR), defined as a/b, where "a" is defined as the number of antimicrobials to which the isolated was resistant and " $b "$ the number of antimicrobials to which the isolated was exposed, and microorganisms with multiple antimicrobial resistance were found in all works (Lima et al., 2006; Hirsch et al., 2006; Resende et al., 2012). This index can be considered an excellent tool for analyzing the dissemination of resistant bacteria in a given population (Pontes et al., 2009).

In this context, considering that the environmental contamination by antimicrobial agents can select, in the environmental micro biota, resistant bacterial strains, and these resistance genes can be passed to human pathogens (Ribeiro et al., 2010), the study of antimicrobial resistance in water environments can help us understand the process of transference of resistance genes among isolated bacteria.

Studies on antimicrobial resistance made in Brazil, evaluated in the last 25 years, clearly reflect the focus of attention given to the economic issues of aquaculture activities. One may consider that large losses in the sector, generated by infectious processes, have driven attention this way. Future studies of resistance in other aquatic environments must still be performed in Brazil, mainly in the North and Northeast regions, where irregular rainfall distribution leads to a shortage of water during dry periods, and turns the tanks into the main sources of supply during the dry season. Thus, concerns about levels of quality, contamination and maintenance of water resources in these areas are very important, as the water is intended for human use or for productive purposes

\section{CONCLUSIONS}

The qualitative and quantitative analysis of studies on bacterial resistance to antimicrobial agents in aquatic environments in Brazil show that the focus of most research is based on economic reason, caused by large losses that infectious processes cause to surveyed resources. The largest number of studies on resistance in aquaculture farms, mostly for the identification of Aeromonas species, is one example. The reduced number of works in the North/Northeast region arouses concern, since, in these areas, the stored water that is used in the dry season can lead to transmission of pathogenic and possibly multi-resistant species. 


\section{REFERENCES}

AMINOV, R. I. Minireview - The role of antibiotics and antibiotic resistance. $\begin{array}{llllllll}\text { Environmental microbiology, } & \text { v. 11, n. 12, p. 2970-2988, }\end{array}$ http://dx.doi.org/10.1111/j.1462-2920.2009.01972.x

CARDONHA, A. M. S. et al. Fecal pollution in water from storm sewers and adjacent seashores in Natal, Rio Grande do Norte, Brazil. International microbiology: the official journal of the Spanish Society for Microbiology, v. 7, n. 3, p. 213-8, set. 2004.

CHAGAS, T. P. G. Detecção de bactérias multirresistentes aos antimicrobianos em esgoto hospitalar no Rio de Janeiro. 2011. 147f. Dissertação (Mestrado em Medicina Tropical) - Fundação Osvaldo Cruz, Rio de Janeiro, 2011.

CHANDRAN, A. et al. Prevalence of multiple drug resistant Escherichia coli Serotypes in a tropical estuary, India. Microbes and Environments, v. 23, n. 2, p. 153-158, 2008. http://dx.doi.org/10.1264/jsme2.23.153

DE MONDINO, S. S. B.; NUNES, M. P. I.; RICCIARDI, LVAN D. Occurrence of Plesiomonas shigelloides in water environments of Rio de janeiro City. Memórias do Instituto Oswaldo Cruz, v. 90, n. 1, p. 1-4, 1995.

DE OLIVEIRA, A. J. F. C.; DE FRANÇA, P. T. R.; PINTO, A. B. Antimicrobial resistance of heterotrophic marine bacteria isolated from seawater and sands of recreational beaches with different organic pollution levels in southeastern Brazil: evidences of resistance dissemination. Environmental monitoring and assessment, v. 169, n. 1-4, p. 375-84, out. 2010. http://dx.doi.org/10.1007/s10661-009-1180-6

DE OLIVEIRA, A. J. F. C.; PINHATA, J. M. W. Antimicrobial resistance and species composition of Enterococcus spp. isolated from waters and sands of marine recreational beaches in Southeastern Brazil. Water research, v. 42, n. 8-9, p. 2242-50, abr. 2008. http://dx.doi.org/10.1016/j.watres.2007.12.002

DING, C.; HE, J. Effect of antibiotics in the environment on microbial populations. Applied microbiology and biotechnology, v. 87, n. 3, p. 925-41, jul. 2010. http://dx.doi.org/10.1007/s00253-010-2649-5

FALCÃO, J. P. et al. Virulence characteristics and epidemiology of Yersinia enterocolitica and Yersiniae other than Y. pseudotuberculosis and Y. pestis isolated from water and sewage. Journal of applied microbiology, v. 96, n. 6, p. 1230-6, jan. 2004. http://dx.doi.org/10.1111/j.1365-2672.2004.02268.x

GONZALEZ-CANDELAS, F. et al. The Evolution of Antibiotic Resistance. Genetics and Evolution of Infectious Diseases, p. 305-337, 2011.

http://dx.doi.org/10.1016/B978-0-12-384890-1.00012-1

HATHA, A. A. M.; GOMATHINAYAGAM, P.; LAKSHMANAPERUMALSAMY, P. Incidence of multiple antibiotic resistant Escherichia coli in the Bhavani River. World journal of microbiology \& biotechnology, v. 9, n. 5, p. 609-10, set. 1993. http://dx.doi.org/10.1007/BF00386309

HIRSCH, D. et al. Identificação e resistência a antimicrobianos de espécies de Aeromonas Móveis isoladas de peixes e ambientes aquáticos. Ciência Agrotecnica, v. 30, n. 6, p. 1211-1217, 2006. 
LIMA, R. M. S. et al. Resistência a antimicrobianos de ambiente de criação e filés de tilápias do nilo (Oreochromis niloticus ). Ciência Agrotecnica, v. 30, n. 1, p. 126-132, 2006.

MIYAKE, D.; KASAHARA, Y.; MORISAKI, H. Distribution and Characterization of Antibiotic Resistant Bacteria in the Sediment of Southern Basin of Lake Biwa. Microbes and Environments, v. 18, n. 1, p. 24-31, 2003.

PEREIRA JÚNIOR, J. D. et al. Concentração inibitória mínima de oxatetraciclina para isolados de Aeromonas hydrophila obtidos de diferentes fontes. Ciência Agrotecnica, v. 30, n. 6, p. 1190-1195, 2006.

PONTES, D. S. et al. Multiple antimicrobial resistance of gram-negative bacteria from natural oligotrophic lakes under distinct anthropogenic influence in a tropical region. Microbial ecology, v. 58, n. 4, p. 762-72, nov. 2009. http://dx.doi.org/10.1007/s00248-009-9539-3

PRADO, T. et al. Detection of extended-spectrum beta-lactamase-producing Klebsiella pneumoniae in effluents and sludge of a hospital sewage treatment plant. Letters in applied microbiology, v. 46, n. 1, p. 136-41, jan. 2008. http://dx.doi.org/10.1111/j.1472-765X.2007.02275.x

REBOUÇAS, R. H. et al. Antimicrobial resistance profile of Vibrio species isolated from marine shrimp farming environments (Litopenaeus vannamei) at Ceará, Brazil. Environmental research, v. 111, n. 1, p. 21-4, jan. 2011. http://dx.doi.org/10.1016/j.envres.2010.09.012

RESENDE, J. A. et al. Multidrug-Resistance and Toxic Metal Tolerance of Medically Important Bacteria Isolated from an Aquaculture System. Microbes and Environments, v. 27, n. 4, p. 449-455, 2012. http://dx.doi.org/10.1264/jsme2.ME12049

RIBEIRO, R. V. Avaliação de sistema de cultivo integrado, a partir da reciclagem de águas residuais submetidas a tratamento primário: pesquisa de espécies dos gêneros Salmonella, Shigella, Vibrio e Aeromonas. 2011. 93f. Tese (Doutorado em Microbiologia) - Universidade do Estado do Rio de janeiro, Rio de Janeiro, 2011.

RIBEIRO, R. $\mathrm{V}$ et al. Incidence and antimicrobial resistance of enteropathogens isolated from an integrated aquaculture system. Letters in applied microbiology, v. 51, n. 6, p. 611-8, dez. 2010. http://dx.doi.org/10.1111/j.1472-765X.2010.02946.x

SALLOTO, G. R. B. et al. Pollution impacts on bacterioplankton diversity in a tropical urban coastal lagoon system. PloS one, v. 7, n. 11, p. e51175, jan. 2012. http://dx.doi.org/10.1371/journal.pone.0051175

SCOARIS, D. D. O. et al. Virulence and antibiotic susceptibility of Aeromonas spp. isolated from drinking water. Antonie van Leeuwenhoek, v. 93, n. 1-2, p. 111-22, 2008. http://dx.doi.org/10.1007/s10482-007-9185-z

SILVA, M. E. Z. et al. Characterisation of potential virulence markers in Pseudomonas aeruginosa isolated from drinking water. Antonie van Leeuwenhoek, v. 93, n. 4, p. 323 34, 2008. http://dx.doi.org/10.1007/s10482-007-9209-8

SOUZA, W. G. S. et al. Resistance profile of Bacteroides fragilis isolated in Brazil. Do they shelter the cfiA gene? The Journal of antimicrobial chemotherapy, v. 45, n. 4, p. 47581, abr. 2000. 